\title{
BCL6 wt Allele
}

National Cancer Institute

\section{Source}

National Cancer Institute. BCL6 wt Allele. NCI Thesaurus. Code C52519.

Human BCL6 wild-type allele is located in the vicinity of 3q27 and is approximately $24 \mathrm{~kb}$ in length. This allele, which encodes B-cell lymphoma 6 protein, is involved in the suppression of transcription. Various lymphoma and leukemia types are associated with aberrant forms of this gene. 